\title{
BRIEF COMMUNICATION OPEN Future increase in extreme El Nino events under greenhouse warming increases Zika virus incidence in South America
}

\author{
V. Brahmananda Rao ${ }^{1}$, K. Maneesha ${ }^{2}$, Panangipalli Sravya ${ }^{3}$, Sergio H. Franchito ${ }^{1}$, Hariprasad Dasari ${ }^{4}$ and Manoel A. Gan ${ }^{1}$
}

The Zika virus (ZIKV) was first found in Zika forest, Uganda in 1947. The disease appeared in the Americas, Northeast Brazil in May 2015. ZIKV propagated rapidly across the Americas and the World Health Organization (WHO) in February 2016 declared this as a public health emergency of international concern. The temperature conditions related to extreme El Niño of 2015-16 were exceptionally favorable for ZIKV spreading in South America. For the recent spreading of ZIKV, in Americas, Northeast Brazil was the starting point and it was associated with the extreme El Niño 2015-16. Paz and Semenza found that there is a striking overlap when the regions with extreme climatic conditions in 1 month are juxtaposed with the geographic distribution of ZIKV in subsequent months. They found that the unique climatic conditions generated by extreme El Niño of 2015-16 are congenial for the dispersal of ZIKV in the Americas. This is not a just coincidence and many authors noted that ZIKV vector Aedes aegypti is strongly dependent on surface climate conditions that occur during extreme El Niño events. Recently a study found that extreme El Niño events will double in future in response to greenhouse warming. Also it was discovered that the increase of extreme El Niño frequency will continue long after $1.5^{\circ} \mathrm{C}$ warming stabilization. We analyze future extreme El Niño events along with associated surface temperatures and calculated the ZIKV quantitatively in future extreme El Niño events and found that large parts of South America are highly favorable for the spread of the disease.

npj Climate and Atmospheric Science (2019)2:4 ; https://doi.org/10.1038/s41612-019-0061-0

\section{INTRODUCTION}

The extreme El Niño events such as those in 1982-83, 1997-98, and $2015-16$ were responsible for several natural disasters. ${ }^{1-11}$ The anomalous climatic conditions associated with extreme El Niño events caused worldwide environmental disruptions including in South America (SA). In SA, the Amazon and Northeast Brazil experienced severe droughts and catastrophic floods occurred in Peru. ${ }^{12}$ For example 1997-98 extreme event alone caused worldwide US\$ 36 billion in damage and an estimated 22,000 people died. ${ }^{12,13}$ In addition to severe changes in climate, the El Niños impact the atmospheric variables such as rainfall, temperature, humidity etc. It is well known that changes in these variables alter several aspects of ecosystems, ${ }^{14}$ disrupt agriculture, cause hurricanes and expand breeding sites of disease-spreading vectors Zika, dengue, and malaria. The study of Hopp and Foley ${ }^{15}$ finds that strong interannual variations in climate significantly affect disease vector ecology. They presented a modeling analysis showing, on a global scale, connections between climate and the development, potential distribution and population dynamics of A.aegypti, the principle vector of Zika. The authors found good agreement between the observed and modeled global distribution of mosquito.

Examining the impact of climate variability on disease intensity is vital especially in regions where the disease is already a global pandemic. Malaria epidemics in African highlands cause high mortality and are strongly related to the climate associated with $\mathrm{El}$ Niño events. For example, Malaria epidemic in a high land region off South West Uganda in 1998 was associated with the extreme El Niño event of 1997-1998. ${ }^{16}$ El Niño events cause the Dengue epidemics in many tropical countries. It was found ${ }^{17}$ that there is a statistically significant correlation between El Niño and dengue epidemic in French Guiana and Indonesia. Also, studies of malaria have revealed large occurrences on the Indian subcontinent, ${ }^{18}$ in Colombia, ${ }^{19}$ Venezuela ${ }^{19,20}$, and Uganda ${ }^{21}$ during El Niño events.

The vectors of ZIKV have established temperature thresholds of survival and these temperature dependent variations regulate their population. If there is sufficient moisture and warmer temperatures, with in the survival ranges exist, mosquito activity increases and decreases the EIP (Extrinsic incubation period) or duration of sporogony. ${ }^{22}$ Peridomestic (living in and around human dwelling) day-biting mosquito's, A.aegypti, feeds preferentially on human blood. The mosquito development and survival strongly depends on temperature. ${ }^{23}$ Further, during warmer months the mosquito's latitudinal range increases as does the density. In addition to temperature, rainfall variations also effect Zika virus breeding. When the rainfall is high the breeding capacity of the mosquito increases because of water logging in ponds, even in dry season during El Niño event over North and South America the stored water for household purposes may also breed mosquitoes.

In view of the highly devastating impacts associated with extreme El Niño events it is necessary to find out whether green house warming will affect the frequency of extreme El Niño events. In a recent work ${ }^{11}$ it was found that the extreme El Niño events will double in future. Here we define the extreme events

\footnotetext{
${ }^{1}$ Instituto Nacional de Pesquisas Espaciais, INPE C.P. 515, São José dos Campos, SP 12245-970, Brazil; ${ }^{2}$ CSIR -National Institute of Oceanography - Regional Centre Visakhapatnam,

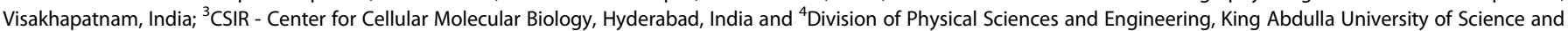
Technology, Tuwal, Saudi Arabia

Correspondence: K Maneesha (kkpalli_manisha@yahoo.com)
}

Received: 1 August 2018 Accepted: 21 December 2018

Published online: 29 January 2019 


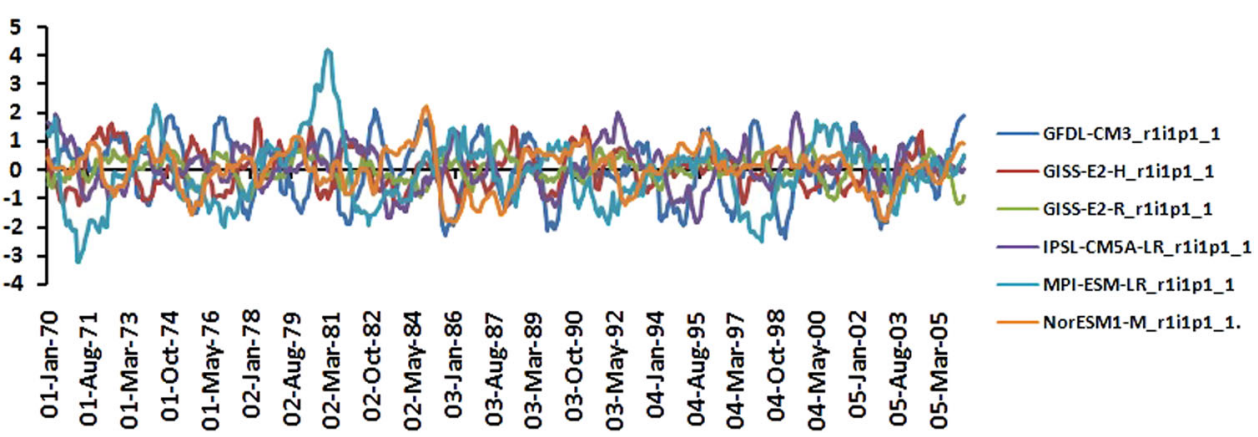

Fig. 1 Niño index from different models of CMIP5

when the Niño $3.4 \mathrm{SST}$ is $\geq 2{ }^{\circ} \mathrm{C}$. This criterion was used by others ggweather.com/enso/oni.htm and reproduces correctly the previous El Niño events including the extreme events of 1982-83, 1997-98, and 2015-16.

\section{RESULTS AND DISCUSSIONS}

Future SST (sea surface temperature) variations over Nino 3.4 have been extracted from CMIP5 ${ }^{24}$ models. In a study of CMIP5 models, Weare ${ }^{25}$ found that in nearly 20 models, surface temperatures, precipitation, and $250 \mathrm{hPa}$ geopotential height departures in the tropics are in good agreement with observations. Overall recent versions of earlier models improved their ability to simulate El Niño teleconnections. The CMIP5 16 models are forced with historical anthropogenic and natural forcings and future greenhouse gas emission scenarios of Special Report on Emission Scenarios (SRES A2) and Representative Concentration Pathway (RCP 8.5) respectively, each covering a 200 year period i.e from 2000-2200. The available models for the selected study period (2070-2100) are: 1. GFDL-CM3_rlilp1_1, 2. GISS-E 2-H_rlilp1_1, 3. GISS-E2-R_rlilp1_1, 4. IPSL-CM5A-LR_rlil1_1, 5. MPI-ESM-LR_rlil1_1, and 6. NorESM1-M_rlil1_1. Of these models, two (1 \&4) are in the selected list of models by Weller et al. ${ }^{26}$ which can successfully simulate their criteria of extreme El Niño events. Ocean Niño index for the Niño 3.4 region has been computed during $2070-2100$ by centered 30-year base periods updated every 5 years according to CPC (Climate Prediction Centre) (http://origin.cpc.ncep.noaa.gov). Different extreme EI Niño years have been identified from different models (Fig. 1). Surface $(2 \mathrm{~m})$ air temperature data from the corresponding models have been taken for the selected years over SA. All the model's data are available with a resolution $<2^{\circ}$. We noted 6 extreme El Niño years: 2074-75, 77, 81, 83, 85, and 99. Since the ZIKV breeds preferentially in austral summer we take January month representing austral summer.

The mean surface $(2 \mathrm{~m})$ air temperature data for the period 1981-2010 in ${ }^{\circ} \mathrm{C}$ in Fig. 2 have been taken from NCEP2. ${ }^{27}$ This figure can be compared with that from Collins et al. ${ }^{28}$ for the period 1976-2007, December, January, and February. The general features seem to agree well, the minimum temperature of $21^{\circ} \mathrm{C}$ between Minas Gerais and São Paulo States, a high temperature zone of $\sim 25^{\circ} \mathrm{C}$ in the Amazon State and a high temperature zone of $29^{\circ} \mathrm{C}$ on the lee side of Andes Mountains.

Surface air temperature anomalies for the 6 extreme El Ninos: $2075,2077,2081,2083,2085$, and 2099 are shown respectively in Fig. 3a-f. The general pattern of anomalies in surface air temperature over SA is very similar in all figures, giving confidence to the results from the CMIP5 models. In all the extreme El Niño years the anomalies are positive over the entire SA. There is a region of high positive anomalies in Bahia and northern Minas Gerais States in Brazil with maximum values of $6^{\circ} \mathrm{C}, 9^{\circ} \mathrm{C}, 8^{\circ} \mathrm{C}, 6^{\circ} \mathrm{C}$,

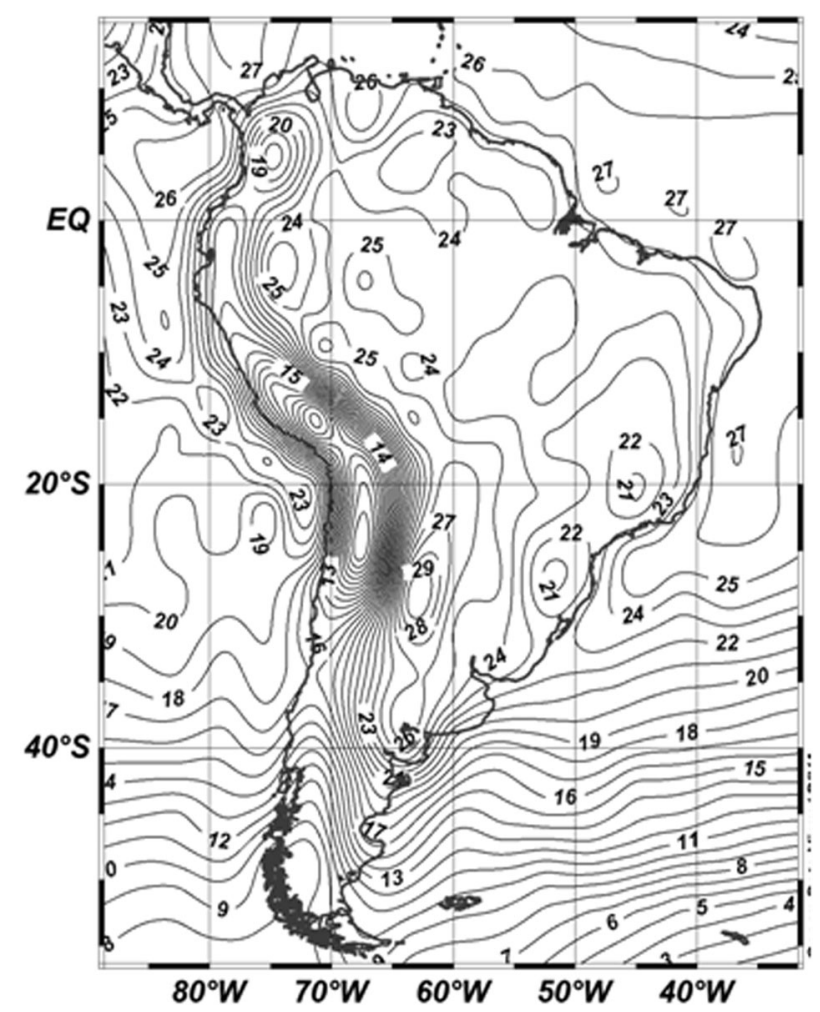

Fig. 2 Mean surface air temperature duirng 1998-2010

$6{ }^{\circ} \mathrm{C}$ in the years $2075,2077,2083,2085$, and 2099, respectively. In the year 2081 the maximum anomaly region is shifted to Mato Grosso do Sul with a value of $7^{\circ} \mathrm{C}$. There is another region of high positive anomalies over Venezuela, Columbia, Guiana, northern Roraima State in Brazil, and the Amazon region. The corresponding maximum values of anomalies in the $6 \mathrm{El}$ Niño years are $\sim 7^{\circ} \mathrm{C}$, $10^{\circ} \mathrm{C}, 11^{\circ} \mathrm{C}, 10^{\circ} \mathrm{C}, 5^{\circ} \mathrm{C}$, and $9^{\circ} \mathrm{C}$, respectively. It is well known that the Amazon region is adversely affected during El Ninos. ${ }^{29}$ During the recent severe El Niño of 2015-16 the warming over the the Amazon forest is termed as record breaking. ${ }^{30}$ The increase of temperature during the future extreme El Niño over the Amazon forest is more than that in the record breaking 2015-16 warming. A third region of high positive anomalies on the lee side of Andes Mountains in the western Argentina and Southern Chile is also seen. The corresponding high anomalies are $8^{\circ} \mathrm{C}, 11^{\circ} \mathrm{C}, 10^{\circ} \mathrm{C}, 10^{\circ}$ $\mathrm{C}, 9^{\circ} \mathrm{C}$, and $8^{\circ} \mathrm{C}$, respectively, in $2075,2077,2081,2083,2085$, and 

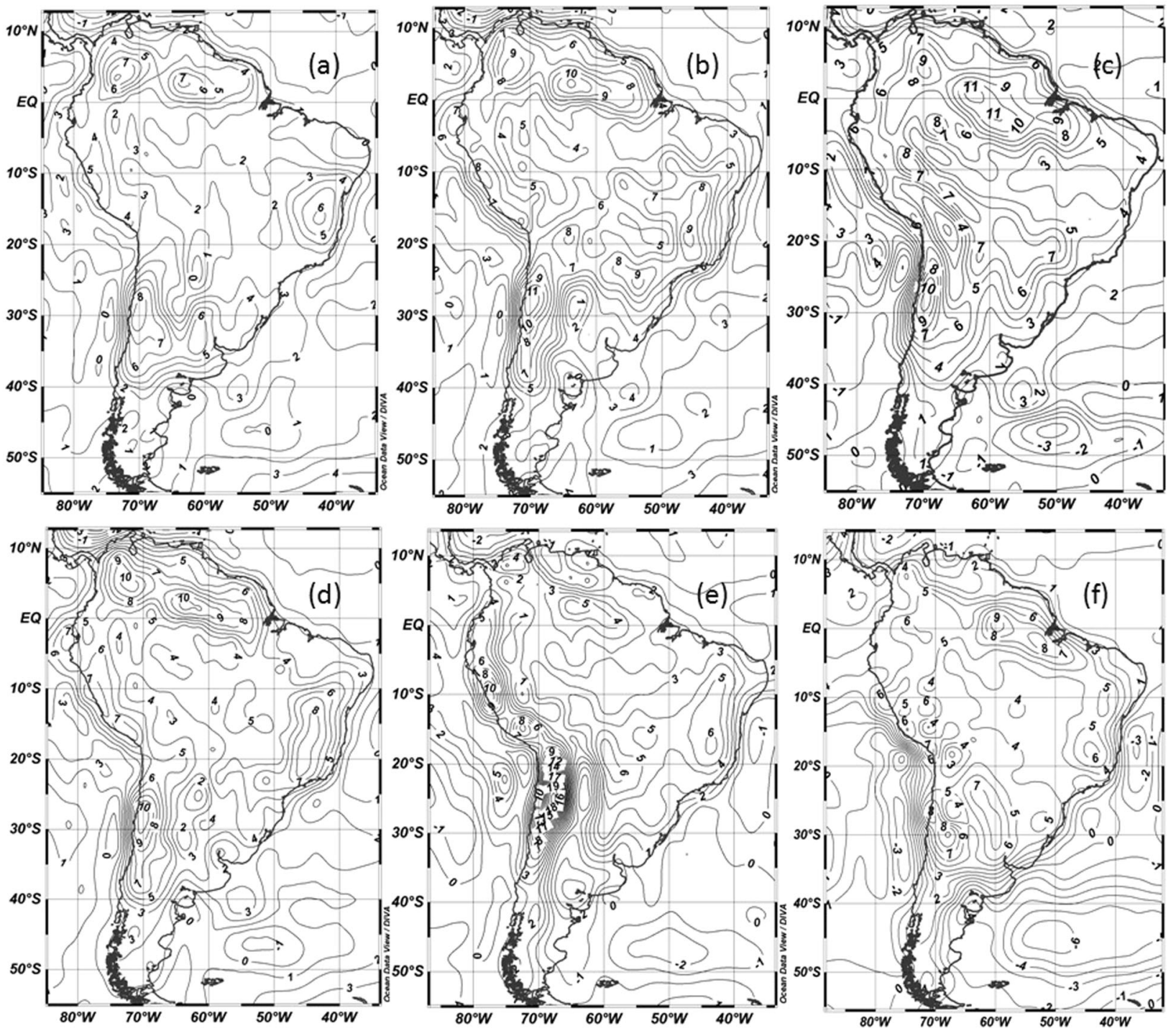

Fig. 3 Air temperature anomalies from the mean to extreme El Niños

2099. In the mean anomaly of all the 6 extreme El Ninos (Fig. 4) also the pattern is similar with the above mentioned three regions of high positive anomalies, with maximum positive anomalies of $5^{\circ} \mathrm{C}, 8^{\circ} \mathrm{C}$, and $10^{\circ} \mathrm{C}$, respectively. The temperatures of 2016 January in these three regions also are high (Fig. 5) with values much less than those in the 6 extreme El Niño years in future (see supplement Fig. 1).

Developmental rate of A.aegypti eggs increases exponentially between $27^{\circ} \mathrm{C}$ and below $40^{\circ} \mathrm{C}$ with increase of temperature. ${ }^{23}$ Since temperatures during future extreme El Niño events (Fig. 3 ) in all the above mentioned three areas are higher than $27^{\circ} \mathrm{C}$ and below $40^{\circ} \mathrm{C}$, these conditions are highly favorable for the proliferation of A.aegypti or Zika virus in SA.

In order to calculate the vectors ability to spread disease among humans, we used the expressions given in Liu-Hermenson et al. ${ }^{31}$ These are given in the methods and data section. VC (Vecotial Capacity) relative to the vector -to - human population ratio can be expressed as

$\mathrm{VC}=a^{2} b_{h} b_{m} e^{-\mu_{m} n} / \mu_{m}$
Regarding the effect of temperatures during extreme El Niño events in Fig. 2, the corresponding biting rates are respectively $0.19,0.21$, and 0.23 (Fig. 6a), that is female A. aegypti feed quicker and more often.

The probability of infection from human to vector per bite $\left(b_{m}\right)$ for the lower temperature range, Fig. $6 \mathrm{~b}$ varies from $0.7-0.9$ for the above mentioned three regions and in figure the corresponding probability for the second temperatures range shows the high probability for almost entire South America indicating the high imminent risk of acquiring the disease in future extreme El Niño events. The probability of transmission from vector to human per bite (bh) is almost similar to the previous Fig. $6 c$

The extrinsic incubation period $(n)$ for higher temperatures during the extreme El Niños varies from 7-14 days in Brazil, Bolivia, Paraguay, and Argentina, whereas the incubation period increases with the increase in the temperature anomalies over Peru and Chile (Fig. 6d).

The mortality rate increases with the increase in temperature anomalies during extreme El Niños in Peru and Chile i.e from 0.03-0.07. In the remaining parts for the temperature ranges of $21-29^{\circ} \mathrm{C}$ the mortality rate varies from $0.03-0.035$ (Fig. 6e) 


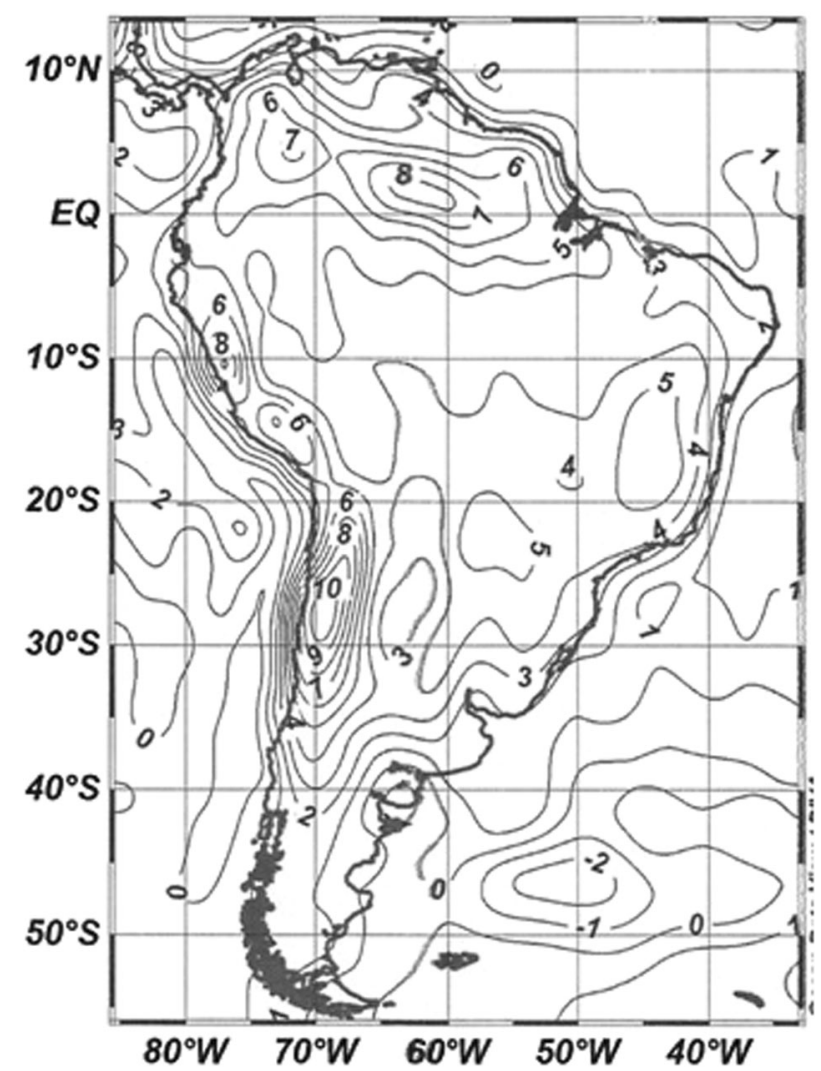

Fig. 4 Mean air temperature anomalies during all extreme El Niños

Vectorial capacity (VC) depicts the spreading of the diseases in human during the future extreme El Niños. It varies from 0.5 to 1.25 where as more spreading has been observed in the Amazon and its surroundings, Bolivia, São paulo state, and Argentina.

The Zika virus epidemic potential VC is shown in Fig. 7. Assuming that the Human-to-mosquito ratio equals $1^{32}$ and using a typical infectious period of 5 days, the threshold value for a dengue epidemic outbreak using VC is estimated to be 0.2 per day. ${ }^{31}$ In this figure (Fig. 7), in all areas that exceed the threshold value of 0.2 per day, the ZIKV epidemic outbreak is imminent (if the other necessary conditions, sufficient presence of humans and vectors exist). In Fig. 7 we see the main favorable regions for the outbreak of ZIKV (more than 0.2) are the three regions of higher temperatures mentioned earlier namely Amazon and its surroundings, Brazil (Southern Minas Gerais, and São paulo state), Bolivia, and Argentina. The high values of 1.25 per day are seen in northern Argentina, Paraguay, Parana, and Matagross states in Brazil and Western Amazon. Also, over large areas in South America a value of 1 per day is seen indicating the high potential of ZIKV outbreak in future extreme El Niño events. The thermal response curves (Fig. 8) also shows that all the vector parameters are increasing with temperature and after reaching the maxima there is a sudden drop in vector transmission and vectorial capacity. Incubation period is continuously decreasing with increasing temperature where as the mortality rate is high at both lower and higher temperature.

Since ZIKV shares a considerable degree of genetic identity and structural homology with other flaviviruses including dengue virus $^{33}$ and there is proof that dengue virus antibodies enhance ZIKV infection, ${ }^{34}$ patients previously affected by Dengue are much likely susceptible to ZIKV infection leading to complications in treatment. In a very recent paper, ${ }^{35}$ studies on mice showed that "during adulthood, ZIKV replication persisted in neonatally infected mice and animals showed increased susceptibility to

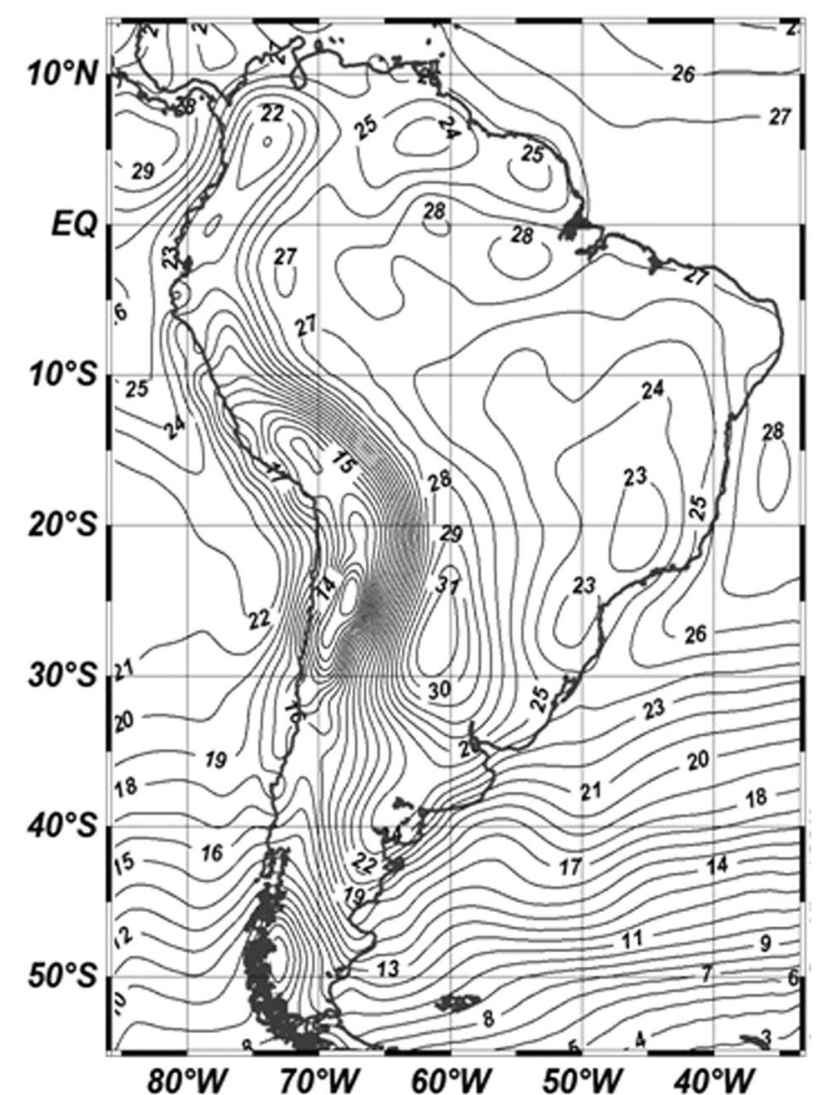

Fig. 5 Air temperature during 2016 extreme El Niño

chemically induced seizures neuro degeneration and brain calcifications". This shows that neonatal ZIKV infection may have long-term complications and may have a lasting impact on brain.

In conclusion, the effect of extreme climate change, under greenhouse warming particularly the increase of temperature by several degrees during extreme El Niños in SA is twofold: (1) it is highly congenial for the increase in the breeding and spread of vector borne diseases such as Zika virus, and (2) is highly prejudicial to delicate balance of biodiversity in the Amazon forest and promote the rapid spreading of ZIKV in São Paulo and nearby states in Brazil, western Argentina, Chile, Venezuela, and Roraima State in Brazil. Thus it is necessary to make policy arrangements for the mitigation of these adverse climate change effects.

\section{METHODS}

The spatial distribution of various vector parameters related to Zika vector A.aegypti has been computed using mechanistic models which are statistically significant from the previous literatures (Liu-Helmersson et al. ${ }^{31}$, and Lambrechts et al., ${ }^{32}$ ). The equations are based on the particular temperature ranges that are favorable for the vector growth.

The equation for the average blood meal frequency i.e. the biting rate ' $a$ ' is

$a(T)=0: 0043 T+0.0943\left(21^{\circ} \mathrm{C} \leq T \leq 32^{\circ} \mathrm{C}\right)$

The probability of infection from human to vector per byte is ' $b_{m}(T)$ ' is

$b_{m}(T)=0: 0729 T-0.9037\left(12.4^{\circ} \mathrm{C} \leq T \leq 26.1^{\circ} \mathrm{C}\right)$

$b_{m}(T)=1\left(26.1^{\circ} \mathrm{C} \leq T \leq 32.5^{\circ} \mathrm{C}\right)$ The prospect of transmission from 


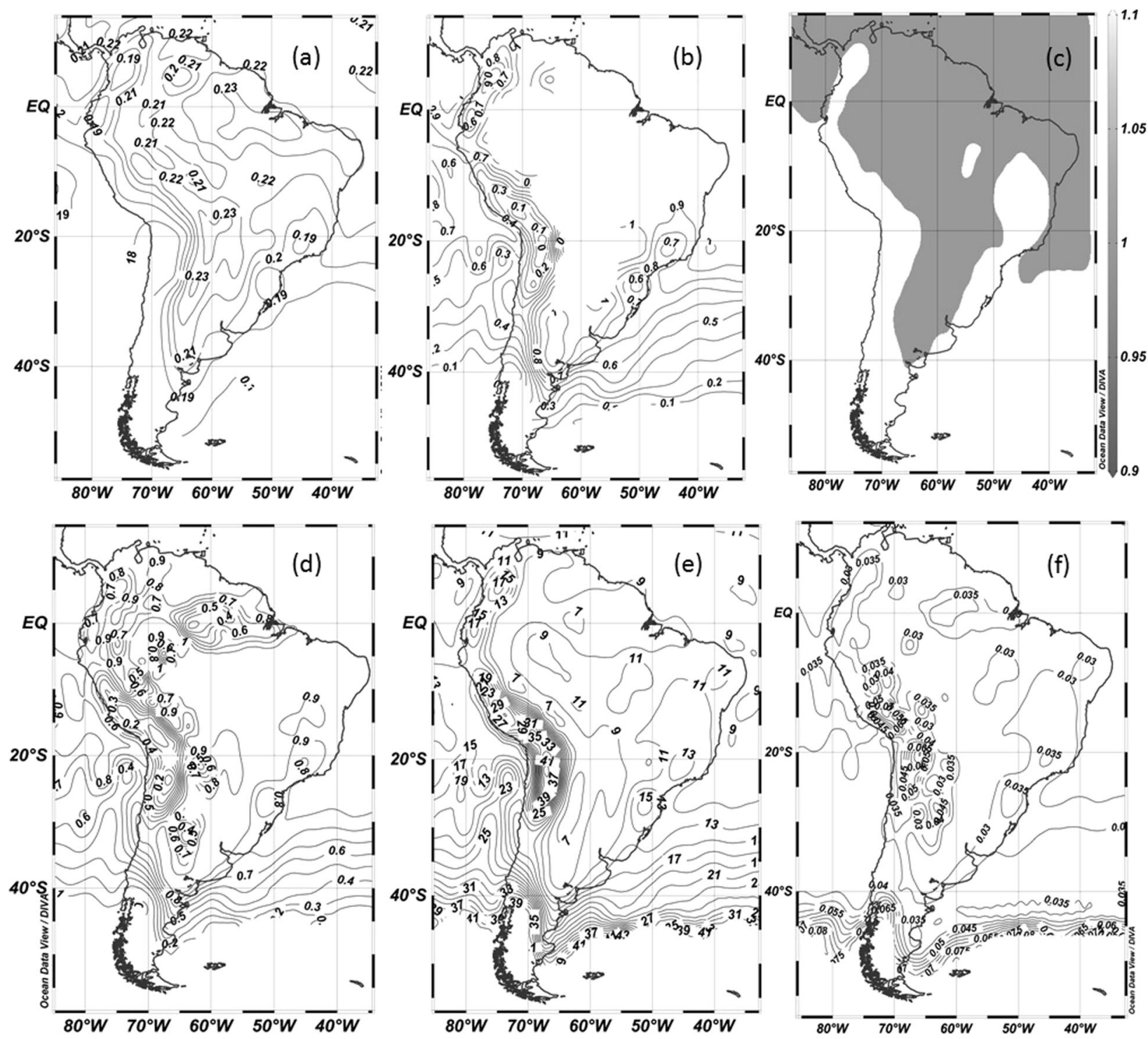

Fig. 6 Spatial variation of vector parameters based on temperature over South America

vector to human per bite ' $b_{h}$ ' is computed by the equation $b_{h}(T)=0.001044 T(T-12.286) \sqrt{32.461-T}(12.286 \leq T \leq 32.461)$ Extrinsic incubation period ' $n$ ' for the temperature range $12-36^{\circ} \mathrm{C}$ is

$n(T)=4+e^{5.15-0.123 T}$

Fourth order polynomial function is used to find the mortality rate by following Yang et al.(2009)

i.e.

$\mu_{m}(T)=0.8692-0.1590+0.01116 T^{2}-3.408 \times 10^{-4} T^{3}+3.809 \times 1$

The above equations are utilized to understand the epidemic potential of ZIKV over South America in the Future El Nino years ${ }^{20,36-38}$

\section{DATA AVAILABILITY}

The temperature (T), SST data has been taken from 4 CMIP5 models (MPI, GFDL, IPSL, and NorESM1) for 7 extreme El Nino years. APDRC regridded CMIP5 data grids into a fixed $1^{\circ}$ by $1^{\circ}$ has been taken from http://apdrc.soest.hawaii.edu. The various vector parameters equations related to Zika vector A.aegypti has been adopted from the mechanistic models (refs. 16, 31)

\section{ACKNOWLEDGEMENTS}

We acknowledge NCEP centre for providing the climatology data. CMIP5 model data have been obtained from APDRC (http://apdrc.soest.hawaii.edu). The lead authors are -thankful to Director INPE Brazil, Director CSIR-NIO, and Scientist-in-Charge NIO RC Visakhapatnam for their support. We are also thankful to heads of the institutes CCMB, Hyderabad and University of Science and technology, King Abdulla for their support and encouragement in carrying out the collaborative work.

\section{AUTHOR CONTRIBUTIONS}

V.B.R. conceived the idea, K.M. made all the calculations and interpretation of El Niño - virus relations, P.S. helped in the interpretation of biological aspects, all the authors contributed for the development of final manuscript. 


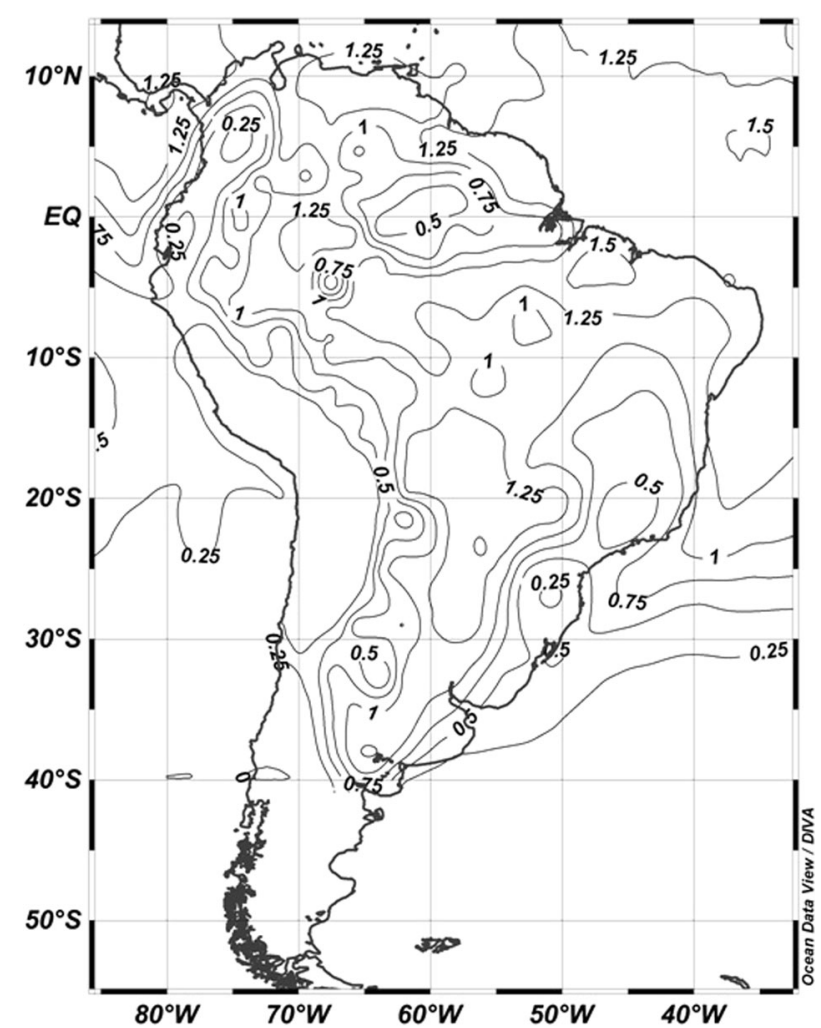

Fig. 7 Spatial variation of vectorial capacity based on temperature over South America

\section{ADDITIONAL INFORMATION}

Supplementary Information accompanies the paper on the npj Climate and Atmospheric Science website (https://doi.org/10.1038/s41612-019-0061-0).

Competing interests: The authors declare no competing interests.

Publisher's note: Springer Nature remains neutral with regard to jurisdictional claims in published maps and institutional affiliations.

\section{REFERENCES}

1. Dick, G. W., Kitchen, S. F. \& Haddow, A. J. Zika virus (I). Isolations and serological specificity. Trans. R. Soc. Trop. Med. Hyg. 46, 509-520 (1952).

2. World Health Organization. Zik-virus infection Brazil and Colombia (http://www. who.intl/csr/don/21ocotober-2015-zika/eu/) (2015)

3. World Health Organization. http.who.int/media centre/statements/2016/zikaupdate-3-16/eu/March 22, 2016. Accessed on 12 April 2016 (2016)

4. Caminade, C. et al. Global risk model for vector-borne transmission of Zika virus reveals the role of El Nino 2015. Proc. Natl Acad. Sci. USA 114, 119-124 (2017).

5. Paz, S. \& Semenza, J. C. El Niño and climate change-contributing factors in the dispersal of Zika virus in the Americas? Lancet 387, 745 (2016).

6. Monaghan, A. J. et al. On the seasonal occurrence and abundance of the zika virus vector mosquito aedes aegypti in the contiguous United States. PLOS Curr. 8, 8 (2016).

7. da Cruz Ferreira, D. et al. Meteorological variables and mosquito monitoring are good predictors for infestation trends of Aedes aegypti, the vector of dengue, chikungunya and Zika. Parasit Vectors 10, 78 (2017).

8. Khormi, H. K. \& Kumar, L. Climate change and the potential global distribution of Aedes aegypti: spatial modelling using geographical information system and CLIMEX. Geospat. Health 2, 405-415 (2014).

9. Martens, W. J. M., Jetten, T. H., Rotmans, J. B. \& Niessen, L. W. Climate change and vector-borne diseases: a global modelling perspective. Glob. Environ. Change 5, 195-209 (1995)

10. Cai, W. et al. Increasing frequency of extreme El Niño events due to greenhouse 559 warming. Nat. Clim. Change 4, 111-116 (2014).

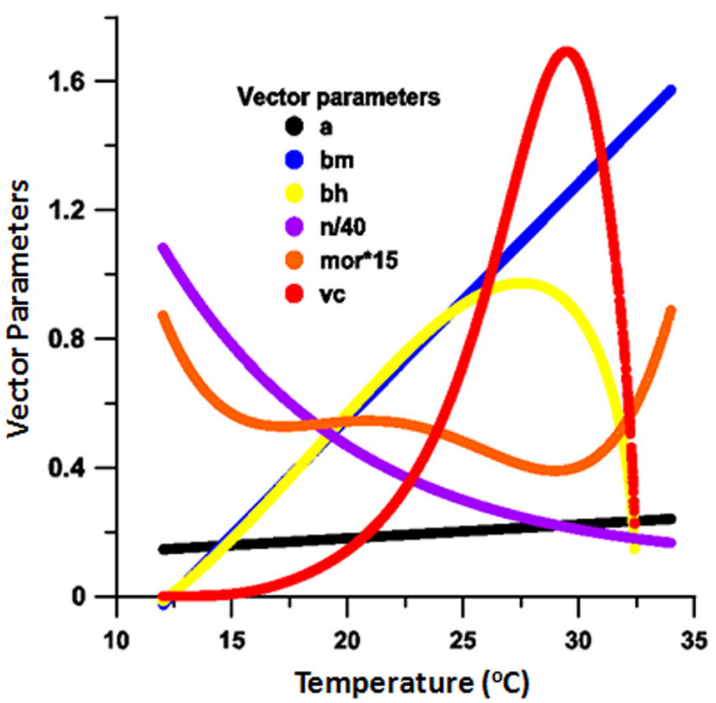

Fig. 8 Thermal response curves of vector parameters and vectorial capacity

11. Wang, G. et al. Continued increase of extreme El Niño frequency long after $1.5 \mathrm{C}$ warming 848 stabilization. Nat. Clim. Change 7, 568-572 (2017).

12. Buizer, J. L., Foster, J. \& Lund, D. Global impacts and regional actions: preparing for the 1997-98 El Niño. Bull. Am. Meteor. Soc. 81, 2021-2139 (2000).

13. Sponberg, K. Navigating the numbers of climatological impact. Compendium of Climatological Impacts, University Corporation for Atmospheric Research, Vol. 1, National Oceanic and Atmospheric Administration, Office of Global Programs, 13 http://www.cip.noaa.gov/docs/navimpact.pdf (1999).

14. Kogan, F. \& Guo, W. Strong 2015-2016 El Niño and implication to global ecosystems from space data. Int. J. Remote Sens. 38, 161-178 (2017).

15. Hopp, M. B. N. \& Foley, J. Global-scale relationships between climate and dengue fever vector Aedes Aegypti. Clim. Change 48, 441-463 (2001).

16. Lindblade, K. A., Walker, E. D., Onapa, A. W., Katungu, J. \& Wilson, M. L. Highland malaria in Uganda: prospective analysis of an epidemic associated with El Niño. Trans. R. Soc. Trop. Med. Hyg. 93, 480-487 (1999).

17. Gagnon, A. S., Bush, A. B. G. \& Smoyer-Tomic, K. E. Dengue epidemics and the El Niño southern oscillation. Clim. Res. 19, 35-43 (2001).

18. Ramesh, C. D. \& Soma, S. El Niño Southern Oscillation as an early warning tool for malaria outbreaks in India. Malar. J. 16, 122 (2017).

19. Alexandre, S., Gagnon Karen, E. \& Smoyer-Tomic Andrew, B. G. Bush the El Niño Southern Oscillation and malaria epidemics in South America. Int. J. Biometeorol. 46, 81-89 (2002).

20. Bouma, M. J. \& Dye, C. Cycles of malaria associated with El Niño in Venezuela. J. Am. Med. Assoc. 278, 1772-1774 (1997).

21. Kovats, S. R. El Niño and health. Bull. WHO 78, 1127-1134 (2000).

22. Patz, J. A., Epstein, P. R., Burke, T. A. \& Balbus, J. M. Globalclimate change and emerging infectious disease. J. Am. Med. Assoc. 275, 217-273 (1996).

23. Focks, D. A., Haile, D. G. \& Mount, G. A. Dynamic life table model for aedes aegypti (diptera: culicidae): analysis of the literature and model development. J. Med. Entomol. 30, 1018-1028 (1999).

24. Taylor, K. E., Stouffer, R. J. \& Meehl, G. A. An overview of CMIP5 and the experiment design. Bull. Am. Meteorol. Soc. 93, 485-498 (2012).

25. Weare, B. C. El Nino teleconnections in CMIP5 models. Clim. Dyn. 41, 2165-2177 (2013).

26. Weller, E. \& Cai, W. Asymmetry in the IOD and ENSO teleconnection in a CMIP5 model ensemble and its relevance to regional rainfall. J. Clim. 26, 5139-5149 (2013).

27. Kanamitsu, M. et al. NCEP-DOE AMIP-II Reanalysis (R-2). Bull. Am. Meteor. Soc. 83, 1631-1643 (2002).

28. Collins, J. M., Chaves, R. R. \& Marques, V. S. Temperature variability over South America. J. Clim. 22, 5854-5869 (2009).

29. Espinoza, J. C. et al. Climate variability and extreme drought in the upper Solimões River (western Amazon Basin): understanding the exceptional 2010 drought. Geophys. Res. Lett. 38, L13406 (2011).

30. Jimenez-Munoz, J. C. et al. Record-breaking warming and extreme drought in the Amazon rainforest during the course of El Niño 2015-2016. Sci. Rep. 6, (2016) 
31. Liu-Helmersson., J., Stenlund, H., Wilder-mith, A. \& Rocklov, J. Vectorial capacity of Aedesaegypti: effects of temperature and implications for global dengue epidemic potential. PLoS One 9, 3 (2014).

32. Lambrechts, L., Paaijmans, K. P., Fansiri, T., Carrington, L. B. \& Kramer, L. D. Impact of daily temperature fluctuations on dengue virus transmission by Aedes aegypti. Proc. Natl Acad. Sci. USA 108, 7460-7465 (2011).

33. Priyamvada, L., Hudson, W., Ahmed, R. \& Wrammert, J. Humoral crossreactivity between Zika and dengue viruses: implications for protection and pathology. Emerg. Microbes Infect. 6, e33 (2017).

34. Paul, L. M. et al. Dengue virus antibodies enhance Zika virus infection. Clin. Transl. Immunol. 5, e117 (2016).

35. Isis Nem de Oliveira, S. et al. Acute and chronic neurological consequences of early-life Zika virus infection in mice. Sci. Transl. Med. 10, 444 (2018).

36. Bouma, M. J. \& van der Kaay, H. J. The El Niño Southern Oscillation and the historic malaria epidemics on the Indian subcontinent and Sri Lanka: an early warning system for future epidemics? Trop. Med. Int. Health 1, 86-96 (1996).

37. Poveda, G. et al. Coupling between annual and ENSO timescales in the malariaclimate association in Colombia. Environ. Health Perspect. 109, 489-493 (2001).
38. Yang, H. M., Macoris, M. L., Galvani, K. C., Andrighetti, M. T. \& Wanderley, D. M Assessing the effects of temperature on the population of Aedes aegypti, the vector of dengue. Epidemiol. Infect. 137, 1188-1202 (2009).

Open Access This article is licensed under a Creative Common Attribution 4.0 International License, which permits use, sharing, adaptation, distribution and reproduction in any medium or format, as long as you give appropriate credit to the original author(s) and the source, provide a link to the Creative Commons license, and indicate if changes were made. The images or other third party material in this article are included in the article's Creative Commons license, unless indicated otherwise in a credit line to the material. If material is not included in the article's Creative Commons license and your intended use is not permitted by statutory regulation or exceeds the permitted use, you will need to obtain permission directly from the copyright holder. To view a copy of this license, visit http://creativecommons. org/licenses/by/4.0/.

C The Author(s) 2019 